\title{
FACTORS ASSOCIATED WITH GROWTH CHANGES IN "GAZELLES"1
}

\author{
ETIENNE ST-JEAN \\ Management Department \\ Université Laval \\ Canada \\ E-mail: etienne.st-jean.1@ulaval.ca

\section{PIERRE-ANDRE JULIEN} \\ INRPME \\ Université du Québec à Trois-Rivières \\ Canada \\ E-mail: Pierre-Andre.Julien@uqtr.ca
}

and

JOSÉE AUDET

Management Department

Université Laval

Canada

E-mail: josee.audet@fsa.ulaval.ca

\begin{abstract}
The goal of this paper is to identify the factors that precede and may cause sudden changes in the pace of growth of high-growth SMEs or gazelles. A retrospective longitudinal case study of seven high growth SMEs that had undergone a total of 14 sudden shifts in growth reveals that a number of events caused the changes of pace. Some were triggered by the entrepreneur's decisions while others resulted from events beyond his/her control. Management's motivation for growth was an important element and this motivation changed over time, being influenced by both success and problems associated with actual growth. The success of growth strategies also appears to depend on the firm's proximity to its client base and its ability to obtain the information required for sound decision-making. Lastly, the availability of tangible and intangible resources was found essential in allowing the company to seize growth opportunities and proximity to the business milieu may help accessing these resources.
\end{abstract}

KEYWORDS: high growth; rapid growth; gazelles; small business; small and medium-sized enterprises; SMEs; entrepreneur; small business owner-manager; discontinuity; growth rate; growth slowdowns; growth spurts; sudden shifts; longitudinal study.

\footnotetext{
${ }^{1}$ St-Jean, É., P.A. Julien, et J. Audet (2008), "Factors associated with growth changes in 'gazelles"', Journal of Enterprising Culture, vol. 16, no. 2, p. 161-188.
} 


\section{INTRODUCTION}

In recent years, high growth firms, commonly known as gazelles, a term coined by Birch (1987), to oppose to mice (for slow growth or stagnated small enterprises) and elephants (for large enterprises), have attracted attention from many small business researchers and case workers. Although gazelles account for between $2 \%$ and $10 \%$ of small and medium-sized firms, in most industrialized countries they generate more than $40 \%$ of all new jobs in surviving companies (Parsley and Dreessen, 2003). Recent research has also shown that they play a significant role in regional restructuring and regional dynamism (Frederick, 2004; Julien, 2007).

However, most of gazelles do not all follow an unbroken or linear growth path. Research has shown that growth rates speed up, slow down or undergo more radical changes (Garnsey and Heffernan, 2005). Over a long period, growth is usually discontinuous, with a high growth spurt being followed by a period of decline or stabilization, and vice-versa (Smallbone et al., 1995; Kemp et al., 2001). Surprisingly, the vast majority of researchers have not commented on the see-saw nature of growth in gazelles. Yet, a better understanding of the causes underlying these variations would be extremely useful, for example in helping these company leaders to better negotiate the ensuing periods of upheaval, which are often difficult for the company.

This paper examines the following research question: Which events precede and may cause sudden changes in the pace of growth of a gazelle? To answer it, we will begin by reviewing the literature that directly or indirectly examines changes in small business growth rates, before presenting the methodology used for the study, presenting the results and discussing their implications.

\section{REVIEW OF THE LITERATURE ON SMALL BUSINESS GROWTH}

There has been no direct research into the causes of growth rate changes in high growth SMEs. For a literature review, the subject must therefore be addressed from another angle. For example, there has been a lot of discussion about business growth in general. The causes of general growth may well apply to gazelles, and could help to structure the theoretical framework of our study. Accordingly, the literature reviewed for the research includes papers on general business growth as well as growth in gazelles. We will begin by presenting the studies in which growth is a dependent variable, highlighting their main growth determinants, before going on to look at studies in which growth is an independent variable. The purpose of this phase is to identify the main elements of the growth process and build the conceptual framework for the research.

\section{Growth as a dependent variable}

\section{The role of the entrepreneur and his or her team}

Entrepreneurs play a key role in the growth of their firms, since their often unstinting commitment is a necessary (although not a sufficient) condition for growth (Davidsson, 1989; Cooper and Artz, 1995; Hughes, 1998; Baum et al., 2001; Isaksen, 2005). The other determinants of growth include the importance for the entrepreneur of creating or buying a company as part of a team rather than individually (Barkham et al., 1996; White and Reynolds, 1996; Watson et al., 2003), having a higher-than-average level of education and experience (Bosworth and Jacobs, 1989; Tan and Tay, 1995; Sapienza and Grimm, 1997), having 
experience of the sector (Barringer et al., 2005), being younger (Kaikkonen, 2006) and delegating, selecting and retaining a strong management team (Hay, 1992; Gundry and Welsch, 1997). However, because what the entrepreneur "is" probably explains growth to a lesser extent than what he or she "does" (Gartner, 1989; Barkham et al., 1996), the actions of the management team, including the long term vision of what they want for their enterprise (Filion, 1991) or their strategic decisions and the impacts of those decision on the firm's resources and configurations, must also be taken into account.

\section{The importance of strategic decisions}

As far as strategy is concerned, gazelles typically diversify their product supply in order to preserve a strong competitive edge, although they never move far from their field of expertise (Fombrun and Wally, 1989; Virtanen and Littunen, 2005). Diversification takes place within a context where innovation plays a significant role (Johnson et al., 1997; Deeds et al., 2000; Julien, 2001). In addition, the products they develop are usually perceived by customers as being of good quality, allowing them to be sold at a price similar to or higher than their competitors' products (Roper, 1997; Sexton and Seale, 1997). The need to export increases when the company's domestic market reaches maturity (Johnson et al., 1997). Growth derives from a proactive strategy based on several different elements (Smallbone et al., 1995; O'Regan et al., 2006) and from the ability to take over a niche thanks to an advantage held by the firm - for example, a high level of technological sophistication (Storey, 1994). Innovation, risk-taking and being proactive also have an impact on organic growth (Antoncic, 2006; McKelvie et al., 2006). Lastly, proximity to a market, which allows clever information to be exchanged on market needs, is said to be crucial for innovation (Barringer et al., 1998; Mäkinen and Selby, 2006).

\section{The need for access to resources}

High growth requires ever-increasing financial resources, for equipment acquisitions and new market development. Several rounds of financing must therefore be planned, and the firm must ensure that its funding sources are able to provide the additional money (Sexton and Seale, 1997). However, bank financing is not always easily available to high growth firms, especially those that are innovative (Audretsch and Lehmann, 2004). This presents a challenge that can be difficult to overcome, particularly if the owner-manager wants to retain control over the firm - a behaviour linked to many high growth firms (Parker et al., 2005). To mitigate their financial requirements, many gazelles offer bonuses or share equity to their employees, while relying on intrinsic motivation as opposed to higher salaries as a means of motivation, allowing them to retain more cash for their operations (Hambrick and Crozier, 1985; Barringer et al., 1998). From the outset, it is crucial for these firms to hire good quality personnel. Gazelles therefore tend to devote a lot of energy to employee recruitment and selection (Hambrick and Crozier, 1985; Johnson et al., 1997). They sometimes obtain resources by developing strategic alliances that provide free access to equipment and advice (Jarillo, 1989; Larson, 1991). Government assistance can also be very useful in meeting the soaring financial needs of high growth companies (Mustar, 2001; Frederick and Bygrave, 2004).

\section{The need to reorganize}

Gazelles must be capable of adjusting and reorganizing themselves in order to incorporate new resources and support innovation (Julien, 2002). Self-adjustment also requires market proximity, so that the firm is able to meet the specific needs of individual customers (Julien, 2001). In addition, management must step away from everyday operations and concentrate instead on organizational change and market development (Smallbone et al., 1995). One way of doing this 
is to delegate as many non-critical functions as possible to a qualified, diversified and multidisciplinary management team (Siegel et al., 1993). The team's job is to formalize routines and manage minor changes, thus allowing the pace of growth to be sustained. A strong organizational culture, teamwork, employee training and good internal communications are also important (Barringer et al., 1998).

\section{Changes in markets and competition}

Elements internal to the firm partly explain firm growth, but the external environment can also affect growth rates. According to some authors, the market can be a factor in firm growth, but in a limited way, because to achieve higher growth than its competitors in its sector, the firm must also implement a more competitive strategy (Hughes, 1998; O'Gorman, 2001). Industrial sectors with a larger percentage of big businesses appear to have a negative impact on small business growth (Penrose, 1959; Pelham, 2000). It is not only the presence of large competitors that acts as an entry barrier for small firms, but also the presence of large buyers; if a large buyer does not select a small firm as a supplier, this can halt the small firm's growth (Hartley and Hutton, 1989).

\section{Growth as an independent variable}

\section{Growth generates complexity}

Growth models (e.g. Steinmetz (1969), Greiner (1972) or Churchill and Lewis (1983)) tend to show that problems in the external environment tend to play a more significant role at the beginning of the life cycle. They gradually give way to problems deriving from internal behaviours or external changes (Dodge and Robbins, 1992), which can trigger severe growth crises. A firm can avoid problems associated with organizational change if it is able to anticipate or even plan the next steps in its development (Galbraith, 1982). Tension is a core element in development stage models, due mainly to the structural changes required for the firm to perform new tasks or attack new problems generated by growth (Kazanjian and Drazin, 1989; Mount et al., 1993). In short, a firm must change if it is to continue to grow at the same pace (Barber et al., 1989; Hay and Williamson, 1991). One of the most important problems encountered in high growth phases is the difficulty of coordinating the new resources required to sustain the growth (new executives, new employees or new equipment). This can affect productivity, among other things, and may require additional cash flow (Garnsey and Heffernan, 2005). New executives can disrupt the team's stability and undermine the culture, thereby upsetting organizational consistency (Hambrick and Crozier, 1985). New employees may sometimes not fit well into the firm, and can disrupt routines, culture or even bring in an undesired trade union. Some researchers have also found that higher levels of complexity in the firm can cause communication problems, leading to conflicts and even causing key employees to leave. All these factors have the potential to reverse a growth trend (Garnsey and Heffernan, 2005).

\section{The conceptual framework}

Some useful elements can be uncovered by treating high growth or general growth as a dependent variable, although this approach has its limitations. One such limitation is the fact that in most cases the analysis concentrates on a given time or period, meaning that there is no way of understanding the cumulative and circumstantial growth process. Studies of this nature must necessarily be longitudinal, to take the time factor into account. Approaches in which growth is treated as an independent variable also have their limitations. They can highlight the 
changes undergone by high growth firms, but are too deterministic and do not really explain why certain firms have irregular or see-saw growth.

The best approach would be a combination of the two, where growth is treated as a process, although it should also be remembered that growth rate is influenced by certain determinants and barriers, and a growing firm will eventually have to change in order to adjust. The literature survey suggests the principal factors influencing firm growth, and these form the conceptual framework of our research. We therefore hypothesize that a change in the pace of growth is influenced by a set of interrelated phenomena that evolve together over time, and constitute the main elements in the growth process.

\section{METHODOLOGY}

Because our research was exploratory in nature, we used a qualitative case study approach. The data were collected longitudinally and retrospectively, since this seemed like the best way of identifying causal theories as well as obtaining the most details and the highest level of precision (Wall and Williams, 1970). The data were as remembered by the company leaders. To avoid cognitive problems such as exaggeration, rationalization, "best light" presentation, simplification and forgetfulness, we followed the suggestion of Wolfe and Jackson (1987) by setting widely spaced time-series interviews, gathering data in 1997 and asking again the same questions, and others, in 2004. Interview subjects were senior managers (at least one from each firm) who were more involved due to their position, and hence better able to describe the process, as pointed out by Glick et al. (1995).

\section{Measuring growth}

Growth was operationalized as growth in the firm's turnover. To standardize the measurements and be able to generalize our findings, only cases involving growth from organic development were retained; in other words, growth resulting from fusions or acquisitions was excluded, since it derives from a different process. The firms studied were small and medium-sized (SMEs) with fewer than 250 employees and less than \$30 million in turnover at the time the observation period began. To be included in the sample, a firm had to have recorded an average annual growth rate ${ }^{1}$ of $20 \%$ for at least four years. The selected firms also needed to have experienced a radical change in their pace of growth during the period under observation, falling into one of the following three categories:

1. Growth spurts were periods of at least two years of overall negative or zero growth, followed by at least four years of growth at a rate of $20 \%$ or more;

2. Growth slowdowns were periods of at least four years of growth at a rate of $20 \%$ or more, followed by at least two years of overall negative or zero growth;

3. Other growth spurts or slowdowns involved variations of roughly $20 \%$ between the average growth rate for the four years preceding the change, and the average of the year in which the change took place and the following three years.

\footnotetext{
${ }^{1}$ The formula used was $\mathrm{GR}_{(\mathrm{n}+1)}=\left(\mathrm{TO}_{(\mathrm{n}+1)}-\mathrm{TO}_{(\mathrm{n})}\right) / \mathrm{TO}_{(\mathrm{n})}$, where GR is growth rate, TO is turnover and $\mathrm{n}$ is the reference year.
} 


\section{The sample}

The sample was composed of seven manufacturing firms that had undergone this type of fluctuation, drawn from a population of 52 gazelles in Québec that were studied ${ }^{1}$ during the second phase of the international OECD survey (2002). In these seven firms, we identified 14 radical changes in the pace of growth (seven spurts and seven slowdowns). As Table 1 shows, the gazelles selected for the study were all SMEs with 1997 turnovers ranging from $\$ 1.8$ million to $\$ 22$ million, and workforces ranging from 17 to 185 employees. The oldest firm was launched in 1948, and the youngest in 1986 .

Table 1 - Information on the firms and respondents questioned for the research

\begin{tabular}{|c|c|c|c|c|c|c|}
\hline $\begin{array}{c}\text { Fictional } \\
\text { name }^{2}\end{array}$ & Sector & $\begin{array}{c}\text { Year } \\
\text { founded }\end{array}$ & $\begin{array}{l}\text { T.O. in } \\
1997\end{array}$ & $\begin{array}{c}\text { Jobs in } \\
1997\end{array}$ & $\begin{array}{l}\text { Position of } \\
\text { respondents } \\
1998\end{array}$ & $\begin{array}{l}\text { Position of } \\
\text { respondents } \\
2004\end{array}$ \\
\hline Foragex & $\begin{array}{c}\text { Drill equipment } \\
\text { manufacturer }\end{array}$ & 1974 & $\$ 22 \mathrm{M}$ & 97 & - CEO & - Controller ${ }^{3}$ \\
\hline Machinex & $\begin{array}{l}\text { Wood equipment and } \\
\text { machinery } \\
\text { manufacturer }\end{array}$ & 1974 & $\$ 8.5 \mathrm{M}$ & 80 & $\begin{array}{l}\text { - CEO } \\
\text { - Founder } \\
\text { - R\&D manager }\end{array}$ & - CEO \\
\hline Transportal & $\begin{array}{l}\text { Metal component } \\
\text { manufacturer }\end{array}$ & 1969 & $\$ 21 \mathrm{M}$ & 185 & $\begin{array}{l}\text { - CEO } \\
\text { - Ops. Mgr. }\end{array}$ & - CEO \\
\hline Propatio & $\begin{array}{c}\text { Furniture } \\
\text { manufacturer }\end{array}$ & 1948 & $\$ 4.7 \mathrm{M}$ & 73 & $\begin{array}{l}\text { - Founding } \\
\text { President }\end{array}$ & $\begin{array}{l}\text { - Founding } \\
\text { President }\end{array}$ \\
\hline Metalex & $\begin{array}{c}\text { Sawmill equipment } \\
\text { manufacturer }\end{array}$ & 1967 & $\$ 6 \mathrm{M}$ & 53 & - President & - President \\
\hline Vitralex & $\begin{array}{l}\text { Weld-free stained } \\
\text { glass manufacturer }\end{array}$ & 1984 & $\$ 3.5 \mathrm{M}$ & 17 & $\begin{array}{l}\text { - Founding Pres. } \\
\text { - Ops. Mgr. } \\
\text { - Founder's son }\end{array}$ & $\begin{array}{l}\text { - Founding } \\
\text { President }\end{array}$ \\
\hline Controltech & $\begin{array}{l}\text { Temperature control } \\
\text { products }\end{array}$ & 1986 & $\$ 1.8 \mathrm{M}$ & $<50$ & $\begin{array}{l}\text { - President } \\
\text { - Gen. Mgr. } \\
\text { - Mgr. Of } \\
\text { Outside Govt. } \\
\text { Agency }\end{array}$ & - President \\
\hline
\end{tabular}

\section{Data collection method}

The first data collection phase, in 1998, used two questionnaires, one with closed questions and the other with open questions, both administered to the leader, an executive or the founder of the firm, followed by an in-depth interview with the owner-manager and, in some cases, with another manager or outside observer who was familiar with the firm. The interviews, which were based on a guide, were recorded and subsequently transcribed verbatim. By using different individuals within the firms (more than only the CEO on five cases) but also a manager from a government agency, it was possible to triangulate ${ }^{4}$ the perceptions of different respondents (Glick et al., 1995). This allowed us to identify the different features of the firm, its organization

\footnotetext{
${ }^{1}$ The 52 companies were selected at random, in the first phase of the international study, from a population of high growth firms identified from a database showing changes in jobs over a ten-year period.

${ }^{2}$ Fictional names have been used to maintain confidentiality.

${ }^{3}$ This person was an external auditor for an accounting firm, and was responsible for the firm's file before being employed by in 1997.

${ }^{4}$ In five of the seven cases, triangulation revealed the contribution of more than one respondent.
} 
and its development, by highlighting elements such as growth triggers, decisions, occasional changes and the problems encountered during changes in the pace of growth.

The second data collection phase took place in 2004, and involved the owner-manager who had taken part in the first phase in six of the seven firms. It consisted in a recorded telephone interview lasting between 20 and 40 minutes, using an interview grid drawn up from an in-depth analysis of the initial questionnaires and interviews. Its purpose was to complete previous responses concerning growth rate change triggers, the strategies devised to deal with them, and the changes that ensued.

\section{Data processing}

The data were processed twice. First, each change in growth rate was converted into an eventstate diagram using the method proposed by Miles and Huberman (1994). Comparisons were then carried out across firms between spurts on the one hand and slowdowns on the other, in order to identify the similarities and differences in each change. The goal was to seek constants between the cases, using comparison to identify a set of characteristics and relationships unique to a given type of change (spurt or slowdown) (D'Amboise and Audet, 2005). The comparisons revealed candidates for main features of growth rate changes in gazelles. The individual diagrams will be presented in the next section.

Once this first process had been completed, as suggested by Miles and Huberman (1994), we prepared a causal diagram. This involved converting the elements from the comparative analysis into measurable variables, and indicating the links between them. This time, spurts and slowdowns were compared with one another in order to identify the variables that affect the growth process in gazelle firms and to propose an emerging theoretical framework for high growth in SMEs. The process is presented after the event-state diagrams.

\section{CHANGES IN GROWTH RATES}

As mentioned earlier, in the first phase of processing the cases were divided into two groups (spurts and slowdowns), which were then subdivided into reactive changes (triggered by events outside the firm) and proactive changes (triggered by internal decisions). Changes of pace usually have several simultaneous causes, as Table 2 shows. In eight of the 14 cases, more than one type of event was identified as a catalyst of the change, and five of the changes were triggered by both a proactive and a reactive situation. For example, the firm wants to grow and acts accordingly, but in the end achieves growth by taking advantage of a favourable situation outside its control; this was the case of Foragex 1993, when the entrepreneur introduced an export strategy (proactive) just as the market underwent significant growth (reactive). The study was unable to measure which of the causes had the greatest impact, or indeed the impact of any of the causes in absolute terms. Its only purpose was to classify the types of events that occurred prior to a radical change in growth rate; no attempt was made to discuss their respective power as triggers. It should be noted that only one of the 14 changes studied was exclusively proactive in other words, the respondent did not think the external environment played any role in triggering the change. In all the other cases, respondents mentioned at least one event beyond their control that had an impact on the firm's growth rate. In addition, in eight of the cases, the respondents said all they did was to suffer the consequences of or adjust to a change in the external environment, which was clearly beyond their control. 
Table 2 - Classification of cases in the event-state diagrams

\begin{tabular}{|c|c|c|}
\hline $\begin{array}{c}\text { The } 14 \text { cases } \\
\text { studied }\end{array}$ & Type of change & Classification in the diagram by type of change \\
\hline Controltech 1995 & Spurt & Proactive, through launch of new products \\
\hline Foragex 1993 & Spurt & $\begin{array}{l}\text { Proactive, through decision to export } \\
\text { Reactive, through change in external environment. }\end{array}$ \\
\hline Machinex 1993 & Spurt & $\begin{array}{l}\text { Proactive, through decision to export } \\
\text { Reactive, through change in external environment }\end{array}$ \\
\hline Métalex 1993 & Spurt & $\begin{array}{l}\text { Proactive, through launch of new products } \\
\text { Reactive, through change in external environment. }\end{array}$ \\
\hline Propatio 1993 & Spurt & $\begin{array}{l}\text { Reactive, through adjustment } \\
\text { Reactive, through change in external environment }\end{array}$ \\
\hline Transportal 1995 & Spurt & Reactive, through adjustment \\
\hline Vitralex 1999 & Spurt & $\begin{array}{c}\text { Proactive, through decision to export } \\
\text { Reactive, through repositioning } \\
\text { Reactive, through change in external environment }\end{array}$ \\
\hline Controltech 1993 & Slowdown & Reactive, through lack of resources for growth \\
\hline Foragex 1998 & Slowdown & Reactive, through change in external environment \\
\hline Machinex 1991 & Slowdown & $\begin{array}{l}\text { Reactive, through management running out of steam } \\
\text { Reactive, through change in external environment }\end{array}$ \\
\hline Machinex 2002 & Slowdown & Reactive, through change in external environment \\
\hline Métalex 1991 & Slowdown & $\begin{array}{l}\text { Reactive, through management running out of steam } \\
\text { Reactive, through change in external environment }\end{array}$ \\
\hline Métalex 1997 & Slowdown & Reactive, through management running out of steam \\
\hline Vitralex 1996 & Slowdown & $\begin{array}{l}\text { Proactive, through launch of new products } \\
\text { Reactive, through change in external environment }\end{array}$ \\
\hline
\end{tabular}

\section{Proactive spurts}

In five of the cases, strategic decisions triggered a growth spurt - either new product launches (two cases) or exports of existing products (three cases). For example, Metalex launched a new product in 1993 and Controltech did the same in 1995. In the case of Metalex, the firm had all the resources it needed to move straight onto the formalization and intensification phase of product research and development. In the case of Controltech, management first had to obtain the resources it needed before formalizing and intensifying its research and development. Strong contacts with government agencies enabled it to obtain the scientific resources (hiring key people), technical resources (training for management) and financial resources it needed for the new product development process. In addition, it introduced a customer need identification mechanism before formalizing and intensifying its new product research. At Metalex, however, much of the necessary development information had already been obtained due to the firm's proximity to its customers. Metalex's management team was also very growth-oriented, and had introduced a series of initiatives aimed at speeding up the firm's growth, increasing its production capacity and introducing a sustained marketing strategy with customers (see Figure $1)$.

Proactive spurts triggered by the decision to export were observed in 1993 at Machinex and Foragex, and in 1999 at Vitralex. Here again, the desire for growth had a direct impact on the decision to export (Figure 2). However, in the case of Foragex, there was also financial pressure due to the significant level of investment required for growth, which made the firm vulnerable in terms of cash flow, especially when the bottom fell out of the domestic market two years later. However, once the decision to export had been made, Foragex developed a very close 
relationship with its new market by opening branch offices and deploying distributor agents. Machinex, on the other hand, did not do this because it was already very close to its local customers. Vitralex did not develop close contacts with either its domestic or its foreign customers. Foragex explained that foreign competition for its products was weak, which allowed its sales to grow more easily. In all three cases, the decision to sell products on new export markets allowed the firm to grow more quickly.

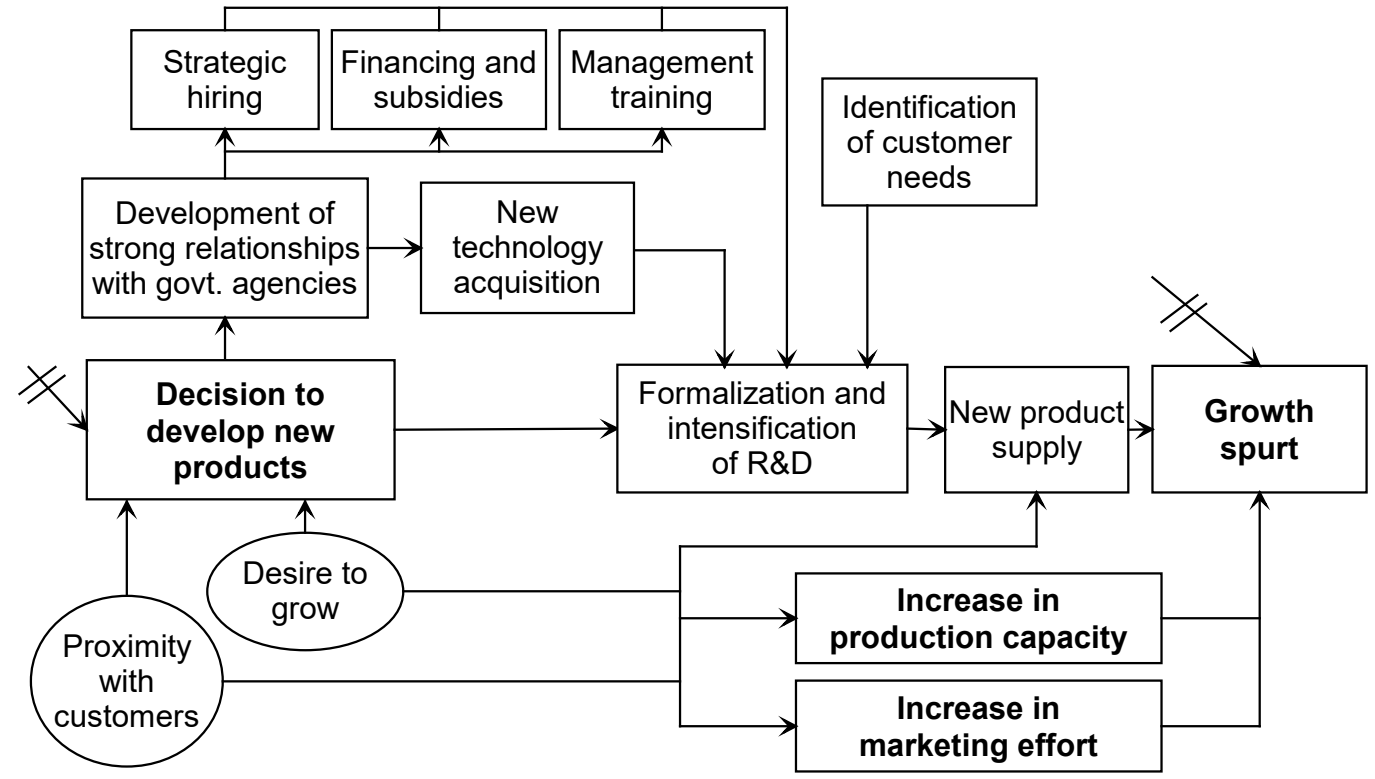

Figure 1 - Proactive spurt through launch of new products (Metalex \& Controltech) ${ }^{1}$

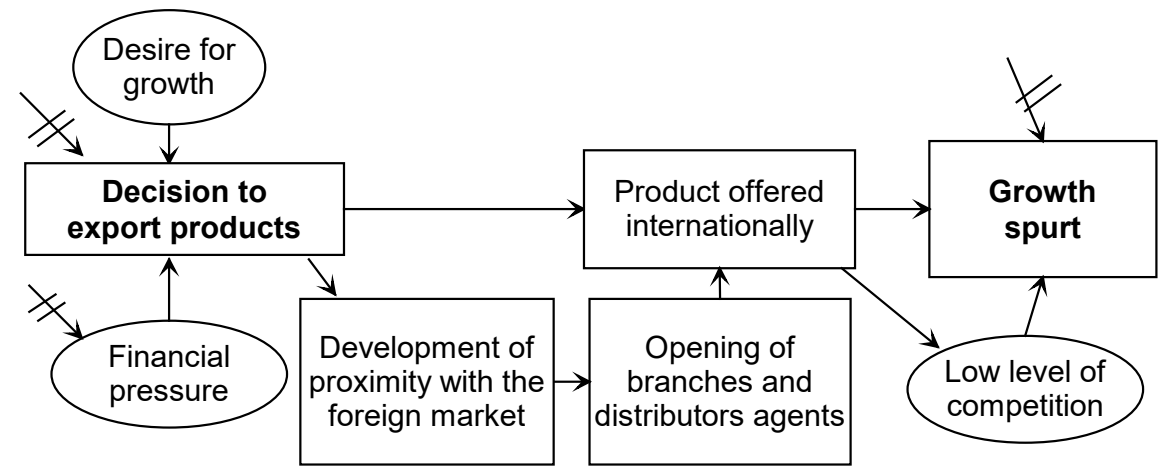

Figure 2 - Proactive spurt through a decision to export (Machinex, Foragex \& Vitralex)

\section{Reactive spurts}

Growth spurts can also be reactions to changes in the external environment, as the firm takes advantage of a new business context. Three types of reactive spurts were identified, namely spurts through adjustments, spurts through repositioning and spurts through taking advantage of an external change.

\footnotetext{
${ }^{1}$ In the diagrams, a square is used to denote an event and a circle to denote a state. Because certain cases involved more than one type of change, broken arrows are used to show that other events or states exist but are not shown in the diagram because they form part of another type of change not illustrated.
} 
Reactive spurts through adjustment were observed in two cases, namely Propatio (1993) and Transportal (1995). In the former case, growth in final demand triggered a reorganization of the market, leading customers to reduce the number of suppliers in favour of Propatio. In the case of Transportal, a major order-giver decided to use the firm as its preferred supplier. In both cases, the management team's desire for growth forced the firms to modernize their production in order to meet new customer requirements. Both firms benefited from changes in the competitive context, because their modernization efforts had been taken into consideration by major customers (Figure 3).

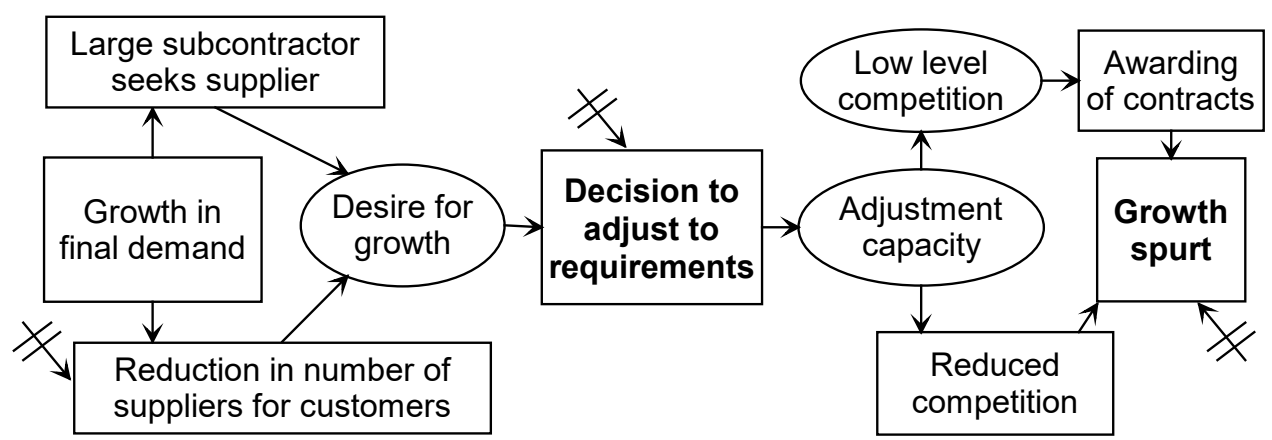

Figure 3 - Reactive spurt through adjustment (Propation \& Transportal)

Reactive spurts through repositioning differ from spurts through adjustment in that they are triggered by more fundamental changes inside the firm. This was the case of Vitralex. The firm was boycotted by its customers after a poor strategic decision (to invade the markets of some of its customers by vertically integrating their operations; this caused a lot of frustration and ultimately led to the customers abandoning Vitralex). The impacts of the decision were not conclusive, since Vitralex was unable to develop its new market sufficiently and gradually lost its old customers. Realizing that it would have to listen more to its customers if it was to survive, Vitralex went back to basics, opting for a strategy of total withdrawal of its decision to integrate vertically. This turned out to be wise, since the firm was able to win back its lost customers and acquire new customers in its original niche (Figure 4).

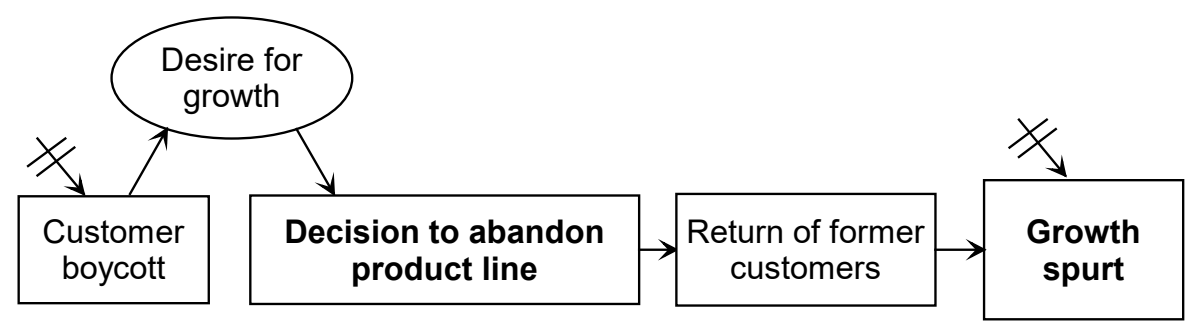

Figure 4 - Reactive spurt through repositioning (Vitralex)

Reactive spurts can also be caused more or less by chance if the firm finds itself in the right place at the right time. Five of the seven firms studied experienced this type of spurt: Foragex, Propatio, Machinex and Metalex in 1993, and Vitralex in 1999. All they did was to take advantage of natural market growth in order to speed up their own growth (Figure 5). Obviously, as for all the types of spurts discussed above, "reactive" spurts may also be triggered simultaneously by "proactive" causes. In short, a radical growth spurt is usually preceded by several different events, some triggered by strategic decisions and others simply by chance. 


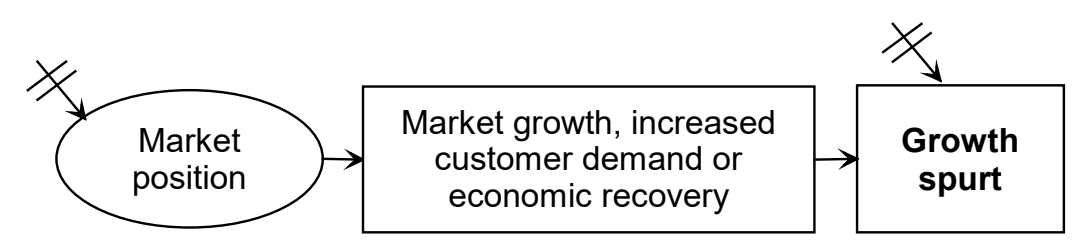

Figure 5 - Reactive spurt through change in the external environment (Foragex, Propatio, Machinex, Metalex and Vitralex)

\section{Proactive slowdowns}

The notion of a proactive slowdown may seem somewhat paradoxical at first glance, but it in fact it is a significant element in the growth process. Vitralex, a firm manufacturing stained glass windows for doors, bought shares in one of its largest customers, a door manufacturer, which became a "customer-partner" as a result. Some time later, the door manufacturer filed for bankruptcy. Vitralex therefore decided to incorporate the firm's operations into its own by purchasing door manufacturing equipment and offering a finished product to major commercial customers. However, Vitralex did not maintain close relationships with its customers, and made this decision without consulting them. They regarded the strategy as a threat, and in reprisal they gradually reduced their purchases from Vitralex. Vitralex's lack of proximity to its customers caused it to misread its market, which explains the growth slowdown (Figure 6). It was the firm's own mistakes that caused its growth to slow.

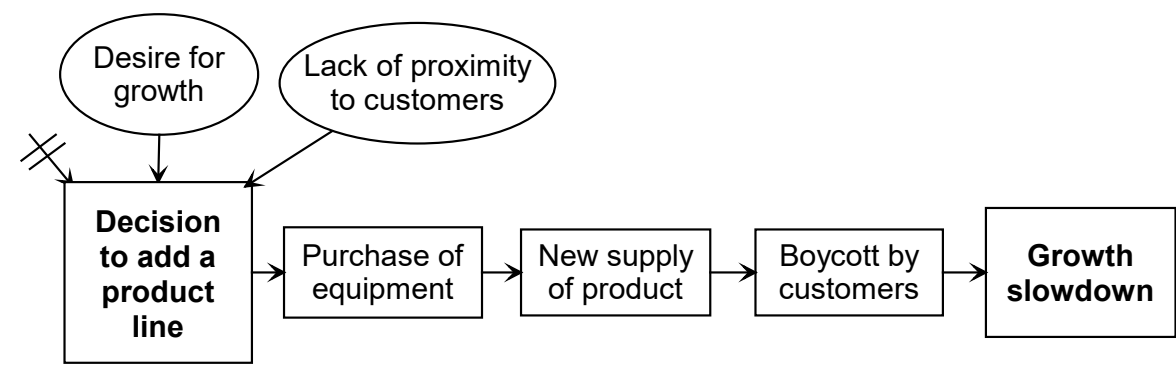

Figure 6 - Proactive slowdown through launch of new products (Vitralex)

\section{Reactive slowdowns}

There are three types of slowdowns triggered by the firm's reaction to internal or external events. The first refers to management over-extension, the second involves a lack of resources to sustain growth, and the third is more or less accidental, when the firm undergoes changes to which it is unable to react - for example because it cannot control elements in its external environment.

The first type - over-extension - occurred at Machinex and Metalex in 1991, and again at Metalex in 1997 (Figure 7). In the case of Machinex, a period of high growth period led to a number of changes in the firm's production. However, routines were not adjusted to support the increase in sales, causing managerial problems and employee communication problems. At the same time, the management team faced internal pressure also caused by high growth, and this eventually led to the introduction of a trade union. This, combined with increased communication and formalization efforts, caused management over-extension. More precisely, top managers were distracted from their growth strategy by more pressing administrative matters and "ran out of steam", as a result of their heavy workload and the intense pressure they felt. In the case of Metalex, the company had just completed a cycle of high growth when it was 
unionized in 1991. In addition, tensions within the management team eventually led to the departure of one of the owner-managers. Some time later, the remaining owner-manager brought in new shareholder-managers, and another management conflict broke out in 1997, leading to the departure of the new partners and dragging the owner-manager into a court battle. Again, the firm had just completed a high growth cycle. For both its slowdowns (1991 and 1997), management could no longer cope with the situation and was unable to sustain the firm's high growth. In 1991 this led to the stoppage of new product development, and in 1997 to a lack of support for growth.

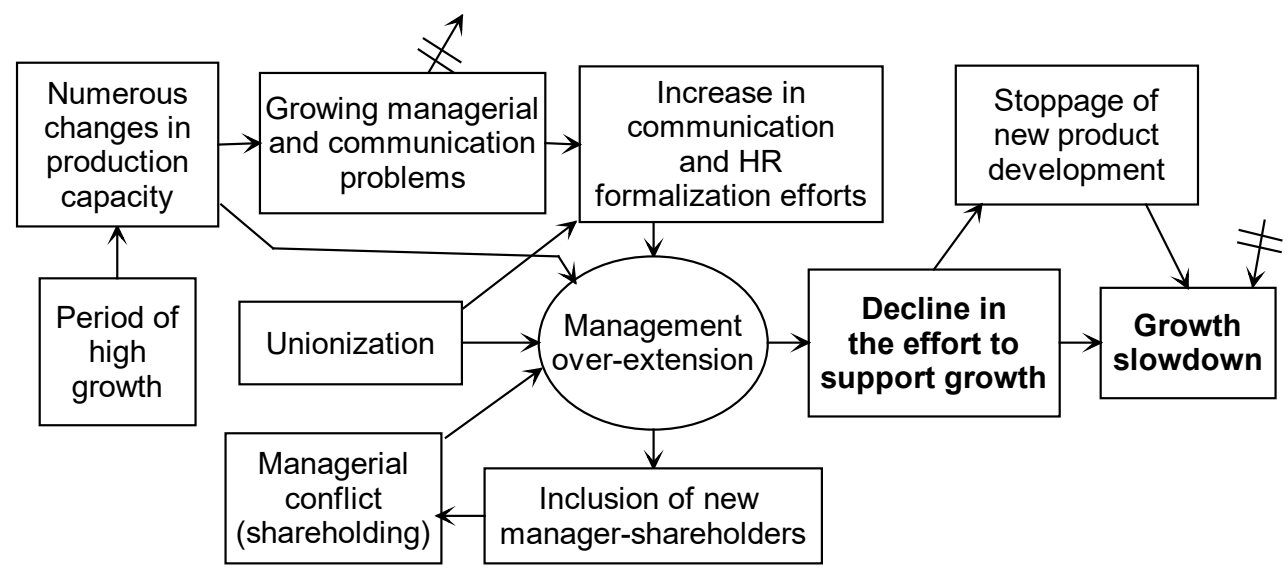

Figure 7 - Reactive slowdown through management running out of steam

A reactive slowdown through lack of resources for growth occurred in the case of Controltech. In 1993, the firm had to slow down its new product development efforts due to a shortage of financial resources and technological know-how (Figure 8). The previous year, it had identified an innovative product that could have met a latent need for its customers, but was unable to develop the product through lack of technological know-how. It did not have the necessary funds to implement the innovation, and was unable to obtain new sources of financing. As a result, its market became saturated and the company's growth slowed considerably.

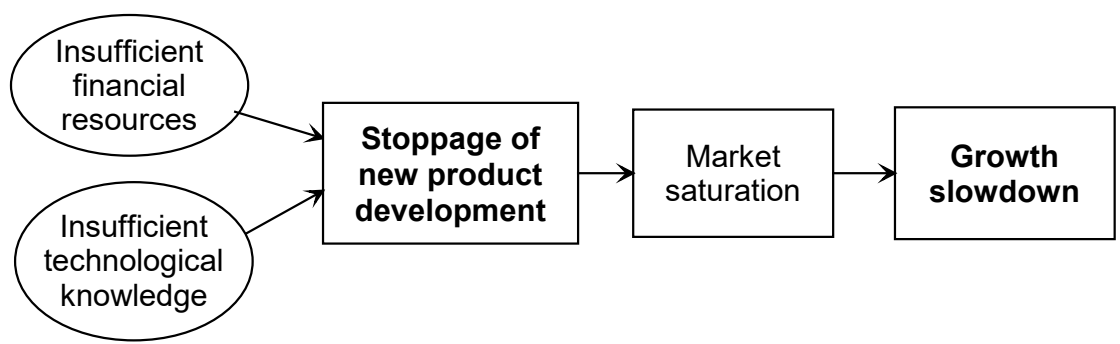

Figure 8-Reactive slowdown through lack of resources to support growth

Lastly, a slowdown can be caused by unexpected external changes that require a certain amount of adjustment time. Five of the seven companies we studied had experienced this type of situation, namely Metalex in 1991, Foragex in 1998, Vitralex in 1996, and Machinex in 1991 and 2002. Examples would include the bankruptcy of a major client, declining competitive capacity or the arrival of a new competitor, all of which can have a significant impact on growth. In the case of Machinex, a company producing sawmill equipment, two external events had serious implications for its customers and hence for its own sales, namely the American policy forcing Canadian lumber exporters to pay import taxes despite the rulings of NAFTA courts, and the rise of the Canadian dollar (Figure 9). 


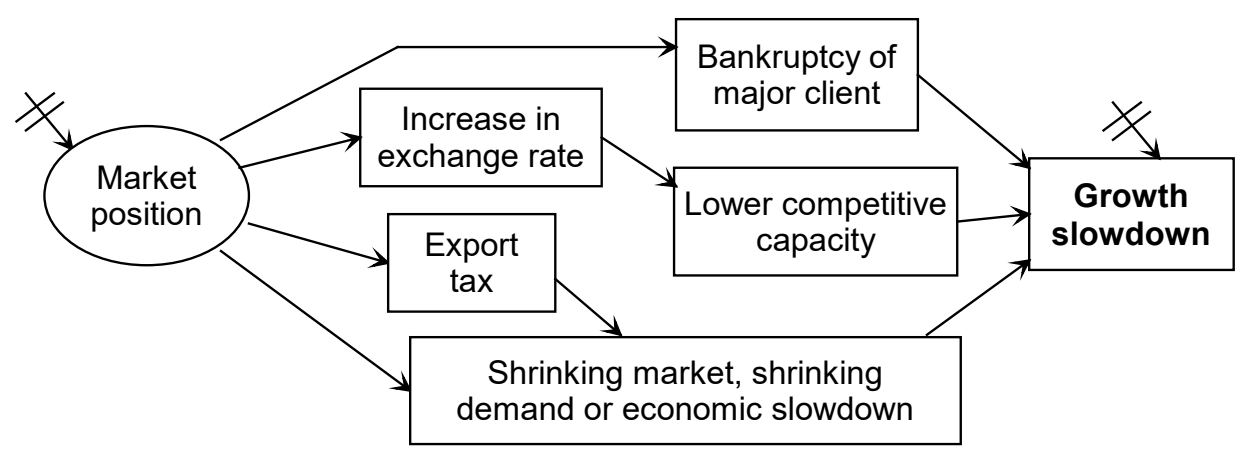

Figure 9-Reactive slowdown through changes in the external environment

The next section examines the factors that influence small business growth and identifies a number of elements that need to be tested in future empirical research.

\section{FACTORS INFLUENCING THE GROWTH OF GAZELLES}

\section{Proximity to customers and strategic information}

The research suggested that the success of strategic initiatives (e.g. new product launch or the decision to export existing products) depends on the firm's proximity to its customers, since proximity provides the information required for decision-makings. Our findings in this respect were clear. Virtually all the "proactive" spurts occurred in contexts where the firm maintained close relationships with its customers (Controltech 1995, Foragex 1993, Machinex 1993 and Metalex 1993). The only case where this was not true terminated with a growth slowdown during implementation of the growth strategy (Vitralex 1996). Controltech 1995 and Foragex 1993 both developed close links to their markets before attempting to implement a growth strategy because they were not sufficiently familiar with the client base in their new target markets. The methods used by the sample firms to develop greater proximity to their customers varied considerably, depending on their managers' styles, market requirements, customer characteristics and so on. The most important element seemed to be the fact of having access to relevant information, rather than how they collected it.

Clearly, proximity to customers appears to be a necessary condition for a successful growth strategy, but it is not a sufficient condition. All the firms whose growth strategies were successful because of their proximity nevertheless experienced growth setbacks at some time or another (Controltech 1993, Foragex 1998, Machinex 1991 and 2002 and Metalex 1991 and 1997). In addition, one of the firms studied (Vitralex 1999) experienced a significant growth spurt despite its lack of proximity to its customers. These examples show that, although the proximity variable is important, it is not the only explanation and other elements also play a role, as we have explained in the review of literature section. In other words, the market proximity variable alone cannot trigger or slow down growth; and the same applies to most of the other variables used for the study. Other research has confirmed that most decisions to launch new products by firms that maintain close links with their markets usually trigger growth spurts (Siegel et al., 1993; Chandler and Baucus, 1996; Barringer et al., 2005; Manev et al., 2005; Lechner et al., 2006). We therefore make the following proposal: 
Proposal 1: A firm that is close to its market can obtain strategic information that may influences its growth by allowing it to pursue opportunities that are in tune with customer needs.

\section{Motivation for growth}

Motivation for growth appears to change over time, depending on whether or not growth actually occurs. During the interviews conducted for this research, the President of Metalex said his desire for growth was very high at the beginning of a high growth period, but declined when problems occurred as a result of the growth. He felt the effort he would have to make to sustain the pace of growth was simply too great, and beyond his capacity. He therefore preferred to aim for less growth, and concentrate instead on management. On the other hand, the President of Controltech said his firm's high growth rate had increased his desire for further growth in the future. In short, firm growth appears to have a positive impact on motivation for growth, while problems arising from growth can have the opposite effect.

Some authors have suggested that perceived opportunities can influence motivation for growth, and that motivation has an impact on actual firm growth (Davidsson, 1991; Vinnell and Hamilton, 1999; Liao et al., 2001). Others have proposed that growth triggers a desire for further growth, while stagnating sales destroy motivation (Kolvereid and Bullvag, 1996; Wiklund and Shepherd, 2003). In short, management's motivation for growth appears to play an important role, among other things by stimulating the owner-manager and his or her team to introduce strategic initiatives that will sustain growth. However, its motivation's connection with strong growth is not a direct one. As several authors have pointed out, motivation is a necessary but not a sufficient condition (Smallbone et al., 1995; Johnson et al., 1997; Hughes, 1998; Orser et al., 1998; Papadaki and Chami, 2002).

Proposal 2: Potential and actual growth have a positive impact on the motivation for growth.

Proposal 3: Potential and actual problems due to high growth have a negative impact on the motivation for growth.

\section{Access to resources and proximity to the milieu}

Access to resources appears to be a major variable in the growth process. A firm wishing to implement a growth strategy must assemble resources if it is to succeed. This was the case of Foragex in 1993; the firm set up an international distribution network to support its strategy of growth through exports. It was also the case of Machinex in 1993; the firm purchased additional equipment to meet the demand from its new international customers. However, not all firms have the resources they need to sustain growth. Controltech (1993), for example, experienced a significant growth slowdown due to a shortage of resources for growth. It had sufficient strategic information to support the development of a new and innovative product, but lacked the expertise and financial resources to complete the project. It spent two years forging contacts with government agencies and a specialist research centre in its sector, and this eventually enabled it to obtain the funds and expertise it needed. As a result, it underwent a radical growth spurt in 1995. The case of Vitralex also illustrates the importance of the firm's milieu in providing access to resources. The firm forged close relationships with its suppliers and regularly exchanged strategic information with them. When it needed to purchase equipment in order to sustain its growth, its suppliers told it where to find a less expensive but equally effective alternative, leaving Vitralex with more resources to support its expansion. 
Other research has also confirmed the importance of resources for growth. Resources may be tangible, such as financing (Brown and Kirchhoff, 1997; Wiklund and Shepherd, 2003) and leading edge equipment, or intangible, such as the time available to management for identifying and seizing opportunities, staff who have the necessary skills (Chandler and Baucus, 1996; Vinnell and Hamilton, 1999), upgrade training and so on. These resources are vital when it comes to seizing and exploiting opportunities and hence fuelling growth (Shelton, 2005). In contrast, a shortage of available resources may cause growth to slow considerably, as was the case for one of the firms studied.

In some cases, proximity to the milieu may help the firm to acquire resources. The literature shows that high growth firms make more use of external resources, and this appears to foster growth (Jarillo, 1989; Macpherson and Holt, 2007). Similarly, some authors suggest that high growth firms tend to be more involved in strategic alliances, among other things to obtain access to resources held by other firms (Wiklund and Shepherd, 2003). Firms that develop greater proximity to their business milieu therefore appear to have better access to the resources they need for their development. We therefore make the following proposals:

Proposal 4: Lack of critical resources (tangibles and intangibles) causes growth setbacks.

Proposal 5: Proximity to the milieu influences access to resources.

\section{Adjustment capacity}

High growth SMEs often go through changes both internally (new working methods, new employees, increases in orders) and externally (new markets, new customers, new suppliers). Although it is difficult to compare the problems encountered by different firms, especially in different contexts, it nevertheless appears that some firms are able to negotiate growth spurts without exhausting their management team, whereas others simply cannot keep up. In our study, the firms that seemed able to adjust to growth were Controltech, which underwent at least ten years of high growth without any signs of flagging on the part of its management team, as well as Foragex (1993) and Vitralex (1999), which both survived long growth spurts without reporting any particular problems in terms of management. In the case of Metalex (1991 and 1997), however, management was unable to keep up with the growth spurts, ultimately abandoning their growth strategy to concentrate on the problems generated by their growth. For Metalex, these problems included conflicts within the management team, and for both Metalex and Machinex, they included conflicts with employees, leading ultimately to unionization.

As far as the ability to adjust to external change is concerned, both Propatio (1993) and Transportal (1995) were able to seize market opportunities that led to growth spurts. In the former case, the firm had to adjust to the demands of retailers by introducing a computerized data exchange system for orders, thus becoming the principal supplier for many retailers and quickly taking over the market. In the latter case, a proposal by a major order-giver for Transportal to become one of its subcontractors required an extensive restructuring of the plant's production and storage facilities. Because Transportal was able to make the required changes, its sales soared. 
Adjustment capacity can explain both spurts and slowdowns. In the case of spurts, changes in the external environment can create opportunities or threats for the firm, requiring a flexible approach. Some authors mention the entrepreneur's ability to adjust to and manage change, even in the external environment (Schindehutte and Morris, 2001). Slowdowns, on the other hand, may be caused more by internal problems to which the firm is unable to adjust, rather than external changes. Garnsey and Heffernan (2005) noted that the pace of growth may exceed the competency and expertise of the firm's decision-makers, especially if they do not have time to identify, examine and find solutions to their problems. The fact that management is unable to keep up, due to tension within its own structure or with employees, or due to problems in adjusting to the internal changes triggered by high growth, can also cause growth to slow. Chandler and Baucus (1996) pointed out that the pace of growth can best be sustained when the firm has a stable and cohesive management team with complementary skills, whereas lack of coherence produces a more irregular growth trajectory. Julien (2002) noted that high growth tends to be more stable if the firm's routines and semi-routines (allowing for adjustments and minor changes) liberate management sufficiently for it to research great opportunities, anticipate major changes in the market and manage the disorder generated by high growth. These observations lead us to the following proposal:

Proposal 6: A firm's capacity to adjust allows it to take advantage of market opportunities and mitigate the negative effects of high growth.

\section{The importance of the market}

In this research, several growth rate changes occurred as a result of changes in the firm's market. Of the 14 changes studied, 11 were impacted positively or negatively by the external environment (Foragex 1993 and 1998, Machinex 1991, 1993 and 2002, Métalex 1991 and 1993, Propatio 1993, Transportal 1995 and Vitralex 1996 and 1999). Although it is not possible to extrapolate these findings to the entire population of high growth SMEs, the influence of the market on growth spurts and slowdowns appears to be considerable. Examples include the cases of Foragex (1998) and Machinex (2002), where their growth slowdowns were due entirely to a shift in the market. The same applies to Propatio (1993) and Transportal (1995), which both experienced significant growth spurts after adjusting to a change in the market, but would not have grown to such an extent without the market change - clearly showing that the firm's market alone can influence its growth rate.

As pointed out by other authors, the firm's market and the demand for its products both have an impact on its growth (Vinnell and Hamilton, 1999; Davidsson et al., 2002; Sims et al., 2002). Generally speaking, a change in the external environment can trigger a significant slowdown in the firm's growth (Chandler and Baucus, 1996). This leads us to the following proposal:

Proposal 7: Market growth or an increase in demand for the firm's products can influence the firm's growth rate.

\section{DISCUSSION AND CONCLUSION}

Many different events may precede a sudden change in growth rate. One way of grouping these events is by intentionality. In other words, a change can be caused either by proactive decisions (i.e., intentional), or by events outside management's control, in which case the decisions are 
reactive. As the case studies suggest, sudden changes in gazelle growth rates are usually often triggered by more than one event at once, and in virtually every case studied, at least one of the events was reactive. Although it is impossible to extrapolate our findings to the entire population of high-growth firms, the results nevertheless highlight the significant role played by chance in triggering growth spurts or slowdowns. The main variables impacting upon growth rates, as identified in this research - including adjustment capacity, access to resources, proximity to customers and motivation for growth - constitute only a potential capacity for growth. That potential can be limited or released by unexpected changes in the firm's environment, such as the bankruptcy of a major competitor or a sudden order from a large order-giver. Vulnerability to the external environment, with its counterpart, flexibility, is indeed a feature of all SMEs and can have a positive or negative impact, since SMES, because of their small size, can organize their environment with lesser possibilities than large firms (Marchesnay and Julien, 1990; Vinnell and Hamilton, 1999; Davidsson et al., 2002)

One must keep in mind that even though changes occur which are out of management's control, the entrepreneur must not remain passive, especially if these changes hinder the firm's growth. Management will have to maintain or further develop client proximity which will enable it to gather information about current or potential changes. Once privy to this information, the firm may have to undergo transformations in order to meet these new needs and obtain new resources if necessary. In short, even though SMEs are more vulnerable than larger firms to changes in their environment, actions taken by management may temper their effects. In light of these considerations, a theoretical framework for changes in SME growth is put forth (see Figure 10).

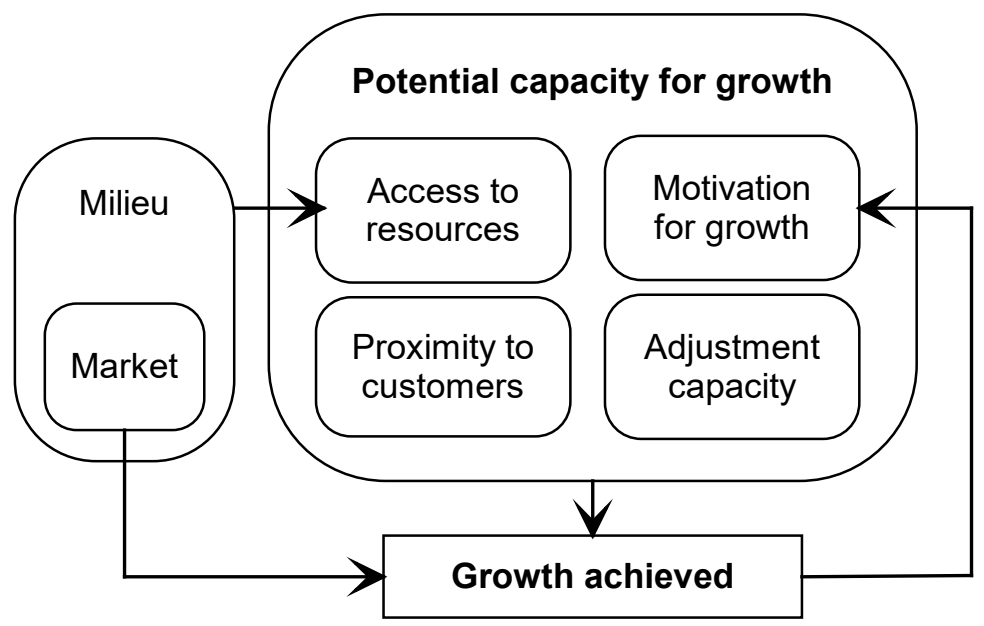

Figure 10 - Framework of variables influencing SME growth

It seems that public decision-makers have three possible paths for helping SMEs that want to grow. First, gazelles need access to a lot of resources if they are to sustain their growth, and as we have observed, the milieu, including business support agencies, can be important in this respect. Second, if gazelles are to take advantage of market opportunities, they must develop mechanisms to maintain their proximity to the market. Training could be given to help entrepreneurs become aware of market knowledge and devise ways of implementing an enterprise culture conducive to exchanges of information between customers and organization 
members. Lastly, gazelles experience many changes as a function of growth and must adjust constantly, both to restructure production and distribution and to take advantage of opportunities that come their way. Accordingly, they need help in addressing the upheavals triggered by their growth, and in remaining flexible and in a position to seize market opportunities.

In this research, we were able to distinguish between proactive and reactive changes, thus improving our understanding of the growth process. The entrepreneur plays a structural role in seizing opportunities and implementing growth strategies. Despite his or her influence, however, it nevertheless remains that radical changes in growth rates are almost always triggered by a set of factors whose individual contributions are impossible to measure out of their context. We still have much to learn about gazelles and fluctuations in their growth rate. Future research will have to consider the phenomenon's complexity and the importance of understanding the dynamics involved between changes in the business environment and management's reactions to such changes.

\section{REFERENCES}

Antoncic, B. (2006). Impacts of diversification and corporate entrepreneurship strategy making on growth and profitability: A normative model. Journal of Enterprising Culture, 14(1): 4963.

Audretsch, D.B. and Lehmann, E.E. (2004). Financing High-Tech Growth: The Role of Banks and Venture Capitalists. Schmalenbach Business Review, 56(4): 340-357.

Barber, J., Metcalfe, S. and Porteous, M. (1989). Barriers to growth: the ACARD study in J. Barber et al. (eds). Barriers to growth in small firms. London: Routledge, 1-19.

Barkham, R.J., Gudgin, G., Hart, M. and Hanvey, E. (1996). The Determinants of Small Firm Growth - An Inter-Regional Study in the United Kingdom 1986-90. London: Jessica Kingsley Publishers.

Barringer, B.R., Jones, F.F. and Lewis, P.S. (1998). A qualitative study of the management practices of rapid-growth firms and how rapid-growth firms mitigate the managerial capacity problem. Journal of Developmental Entrepreneurship, 3(2): 97-122.

Barringer, B.R., Jones, F.F. and Neubaum, D.O. (2005). A quantitative content analysis of the characteristics of rapid-growth firms and their founders. Journal of Business Venturing, 20(5): 663-687.

Baum, R.J., Locke, E.A. and Smith, K.G. (2001). A Multidimensional Model of Venture Growth. Academy of management journal, 44(2): 292-303.

Birch, D.L. (1987). Job Creation in America. New York: Free Press.

Bosworth, D. and Jacobs, C. (1989). Management attitudes, behaviour, and abilities as barriers to growth in J. S. Metcalfe (ed). Barriers to growth in small firms. London: Routledge, 20-38.

Brown, T.E. and Kirchhoff, B.A. (1997). The Effects of Resource Availability and Entrepreneurial Orientation on Firm Growth. Babson Park: Babson College. Retrieved 15/05, 2006, from: http://www.babson.edu/entrep/fer/papers97/kirtchoff/kir1.htm.

Chandler, G.N. and Baucus, D.A. (1996). Gauging performance in emerging businesses: Longitudinal evidence and growth pattern analysis. Babson Park: Babson College. Retrieved 10/09, 2004, from: http://www.babson.edu/entrep/fer/. 
Churchill, N.C. and Lewis, V.L. (1983). The five stages of small business growth. Harvard Business Review, 61(3): 30-50.

Cooper, A.C. and Artz, K.W. (1995). Determinants of satisfaction for entrepreneurs. Journal of Business Venturing, 10(6): 439-457.

D'Amboise, G. and Audet, J. (2005). La comparaison inter-sites : une voie pour la recherche en gestion. Québec: Presses de l'Université Laval.

Davidsson, P. (1989). Entrepreneurship - and after ? A Study of Growth Willingness in Small Firms. Journal of Business Venturing, 4(3): 211-226.

Davidsson, P. (1991). Continued Entrepreneurship: Ability, Need, and Opportunity as Determinants of Small Firm Growth. Journal of Business Venturing, 6(6): 405-429.

Davidsson, P., Kirchhoff, B., Hatemi-J, A. and Gustavsson, H. (2002). Empirical Analysis of Business Growth Factors Using Swedish Data. Journal of Small Business Management, 40(4): 332-349.

Deeds, D.L., Decarolis, D. and Coombs, J. (2000). Dynamic capabilities and new product development in high technology ventures: An empirical analysis of new biotechnology firms. Journal of Business Venturing, 15(3): 211-229.

Dodge, R.H. and Robbins, J.E. (1992). An empirical investigation of the organizational life cycle model for small business development and survival. Journal of Small Business Management, 30(1): 27-34.

Filion, L.-J. (1991). Vision and relation: Elements for an entrepreneurial metamodel. International Small Business Journal, 9(2): 26-40.

Fombrun, C.J. and Wally, S. (1989). Structuring Small Firms for Rapid Growth. Journal of Business Venturing, 4(2): 107-122.

Frederick, H.H. (2004). Towards high growth enterprise. International Journal of Entrepreneurship and Small Business, 1(3/4): 238-248.

Frederick, H.H. and Bygrave, W. (2004). How we finance our new and growing firms. International Journal of Entrepreneurship and Small Business, 1(3/4): 287-293.

Galbraith, J. (1982). The stages of growth. The Journal of Business Strategy, 3(4): 70-79.

Garnsey, E. and Heffernan, P. (2005). Growth setbacks in new firms. Futures, 37(7): 675-697.

Gartner, W.B. (1989). "Who Is an Entrepreneur ?" Is the Wrong Question. Entrepreneurship Theory and Practice, 13(4): 47-68.

Glick, W.H., Huber, G.P., Miller, C.C., Doty, D.H. and Sutcliffe, K.M. (1995). Studying Changes in Organizational Design and Effectiveness - Retrospective Event Histories and Periodic Assessments in G. P. Huber and A. H. Van de Ven (eds). Longitudinal Field Research Methods - Studying Processes of Organizational Change. Thousand Oaks: Sage Publications.

Greiner, L.E. (1972). Evolution and revolution as organizations grow. Harvard Business Review, 50(4): 64-73.

Gundry, L.K. and Welsch, H.P. (1997). The Ambitious Entrepreneur: Attributes of Firms Exhibiting High Growth Strategies. Babson Park: Babson College. Retrieved 15/05, 2003, from:

http://www.babson.edu/entrep/fer/.

Hambrick, D.C. and Crozier, L.M. (1985). Stumblers and Stars in the Management of Rapid Growth. Journal of Business Venturing, 1(1): 31-45.

Hartley, K. and Hutton, J. (1989). Large purchasers in J. Barber et al. (eds). Barriers to growth in small firms. London: Routledge, 105-127. 
Hay, M. (1992). Barriers to Small Firm Growth. Babson College. Retrieved 05/05, 2006, from: http://www.babson.edu/entrep/fer/.

Hay, M. and Williamson, P. (1991). Strategic Staircases: Planning the Capabilities Required for Success. Long Range Planning, 24(4): 36-43.

Hughes, A. (1998). Growth Constraints on Small and Medium-Sized Firms (Working Paper No. 107). Cambridge: University of Cambridge.

Isaksen, E. (2005). Growth objectives in Norwegian start-up businesses. International Journal of Entrepreneurship and Small Business, 2(1): 17-26.

Jarillo, J.C. (1989). Entrepreneurship and Growth: The Strategic use of External Resources. Journal of Business Venturing, 4(2): 133-147.

Johnson, J., Baldwin, J. and Hinchley, C. (1997). Les jeunes entreprises montantes: se donner les moyens de survivre et de croître: Statistique Canada - Division de l'analyse microéconomique.

Julien, P.-A. (2001). Les PME à forte croissance et la métaphore du jazz. Comment gérer l'improvisation de façon cohérente. Revue Internationale PME, 14(3-4): 129-162.

Julien, P.-A. (2002). Les PME à forte croissance: l'exemple de 17 gazelles dans 8 régions du Québec. Ste-Foy, Québec: Presses de l'Université du Québec.

Julien, P.-A. (2007). A Theory of Local Entrepreneurship in the Knowledge Economy. Cheltemhan, UK: Edward Elgar.

Kaikkonen, V. (2006). Exploring the dilemmas of small business growth - The case of rural food-processing micro firms. Journal of Enterprising Culture, 14(2): 87-104.

Kazanjian, R.K. and Drazin, R. (1989). An empirical test of a stage of growth progression model. Management Science, 35(12): 1489-1503.

Kemp, R., Verhoeven, W. and Kreijen, M. (2001). La croissance et la décroissance des entreprises aux Pays-Bas. Revue Internationale PME, 14(3-4): 189-210.

Kolvereid, L. and Bullvag, E. (1996). Growth intentions and actual growth: The impact of entrepreneurial choice. Journal of Enterprising Culture, 4(1): 1-17.

Larson, A. (1991). Partner networks: Leveraging external ties to improve entrepreneurial performance. Journal of Business Venturing, 6(3): 173-188.

Lechner, C., Dowling, M. and Welpe, I. (2006). Firm networks and firm development: The role of the relational mix. Journal of Business Venturing, 21(4): 514-540.

Liao, J., Welsch, H.P. and Pistrui, D. (2001). Environmental and individual determinants of entrepreneurial growth: An empirical examination. Journal of Enterprising Culture, 9(3): 253-272.

Macpherson, A. and Holt, R. (2007). Knowledge, learning and small firm growth: A systematic review of the evidence. Research Policy, 36(2): 172-192.

Mäkinen, P. and Selby, J.A. (2006). Challenges to the growth of Finnish woodworking SMEs. International Journal of Entrepreneurship and Small Business, 3(5): 594-606.

Manev, I.M., Gyoshev, B.S. and Manolova, T.S. (2005). The role of human and social capital and entrepreneurial orientation for small business performance in a transitional economy. International Journal of Entrepreneurship and Innovation Management, 5(3/4): 298-318.

Marchesnay, M. and Julien, P.-A. (1990). Small business as space of transaction. Entrepreneurship and Regional Development, 2(2): 267-277.

McKelvie, A., Wiklund, J. and Davidsson, P. (2006). A Resource-Based View on Organic and Acquired Growth in J. Wiklund et al. (eds). Advances in Entrepreneurship, Firm Emergence and Growth. Amsterdam: Elsevier, 175-194. 
Miles, M.B. and Huberman, M.A. (1994). Qualitative Data Analysis: an expanded sourcebook. 2 ed. Thousand Oaks: Sage Publications Inc.

Mount, J., Zinger, T.J. and Forsyth, G.R. (1993). Organizing for Development in the Small Business. Long Range Planning, 26(5): 111-120.

Mustar, P. (2001). Diversité et unité des entreprises à forte croissance du secteur manufacturier en France. Revue Internationale PME, 14(3-4): 67-90.

O'Gorman, C. (2001). The sustainability of growth in small- and medium-sized enterprises. International Journal of Entrepreneurial Behaviour \& Research, 7(2): 60-75.

O'Regan, N., Ghobadian, A. and Gallear, D. (2006). In search of the drivers of high growth manufacturing SMEs. Technovation, 26(1): 30-41.

OECD (2002). High-growth SMEs and Employment. Paris: OECD.

Orser, B.J., Hogarth-Scott, S. and Wright, P. (1998). On the Growth of Small Enterprises: The Role of Intentions, Gender and Experience. Babson Park: Babson College. Retrieved 05/05, 2006, from:

http://www.babson.edu/entrep/fer/papers98/XIII/XIII_A/XIII_A.html.

Papadaki, E. and Chami, B. (2002). Les facteurs déterminants de la croissance des microentreprises au Canada: Direction générale de la politique de la petite entreprise - Industrie Canada.

Parker, S.C., Storey, D.J. and van Witteloostuijn, A. (2005). What Happens to Gazelles? The Importance of Dynamic Management Strategy. Durham, U.K.: University of Durham. Retrieved 12/05, 2006, from:

http://www.dur.ac.uk/resources/dbs/businessschool/research\%20paper012.pdf.

Parsley, C. and Dreessen, E. (2003). Projet sur les entreprises en croissance: Principales constatations. Ottawa: Direction générale de la politique de la petite entreprise, Industrie Canada.

Pelham, A.M. (2000). Market Orientation and Other Potential Influences on Performance in Small and Medium-Sized Manufacturing Firms. Journal of Small Business Management, 38(1): 48-67.

Penrose, E.T. (1959). The Theory of the Growth of the Firm. Oxford, U.K.: Oxford University Press.

Roper, S. (1997). Product Innovation and Small Business Growth: A Comparison of the Strategies of German, U.K. and Irish Companies. Small Business Economics, 9: 523-537.

Sapienza, H.J. and Grimm, C.M. (1997). Founder Characteristics, Start-Up Process, and Strategy/Structure Variables as Predictors of Shortline Railroad Performance. Entrepreneurship: Theory \& Practice, 22(1): 5-24.

Schindehutte, M. and Morris, M.H. (2001). Understanding strategic adaptation in small firms. International Journal of Entrepreneurial Behaviour \& Research, 7(3): 84-107.

Sexton, D.L. and Seale, F.I. (1997). Leading Practices of Fast Growth Entrepreneurs - Pathway for High Performance. Kansas City, Missouri: National Center for Entrepreneurship Research.

Shelton, L.M. (2005). Scale barriers and growth opportunities: A resource-based model of new venture expansion. Journal of Enterprising Culture, 13(4): 333-357.

Siegel, R., Siegel, E. and Macmillan, I.C. (1993). Caracteristics distinguishing high-growth ventures. Journal of Business Venturing, 8(2): 169-180.

Sims, R., Breen, J. and Ali, S. (2002). Small business support: Dealing with the impediments to growth. Journal of Enterprising Culture, 10(4): 241-256. 
Smallbone, D., Leigh, R. and North, D. (1995). The caracteristics and strategies of high growth SMEs. International Journal of Entrepreneurial Behaviour \& Research, 1(3): 44-62.

Steinmetz, L.L. (1969). Critical stages of small business growth - When they occur and how to survive them. Business Horizons, 12: 29-36.

Storey, D.J. (1994). Understanding The Small Business Sector. London: Routledge.

Tan, W.C.M. and Tay, R.S.T. (1995). Factors contributing to the growth of SMEs: The Singapore case. Journal of Enterprising Culture, 3(2): 197-210.

Vinnell, R. and Hamilton, R.T. (1999). A historical perspective on small firm development. Entrepreneurship Theory and Practice, 23(4): 5-18.

Virtanen, M. and Littunen, H. (2005). Picking the Winners - Explaining Factors of New Venture Growth. ICSB World Conference, Washington, DC, International Council of Small Business.

Wall, W.D. and Williams, H.L. (1970). Longitudinal Studies \& the Social Sciences. London: Heinemann Educational Books Ltd.

Watson, W., Stewart, W.H.J. and BarNir, A. (2003). The effects of human capital, organizational demography, and interpersonal processes on venture partner perceptions of firm profit and growth. Journal of Business Venturing, 18(2): 145-164.

White, S.B. and Reynolds, P.D. (1996). Government programs and high growth new firms. Babson Park: Babson College. Retrieved 24/02, 2004, from: http://www.babson.edu/entrep/fer/.

Wiklund, J. and Shepherd, D. (2003). Aspiring for, and Achieving Growth: The Moderating Role of Resources and Opportunities. Journal of Management Studies, 40(8): 1919-1941.

Wolfe, J. and Jackson, C. (1987). Creating Models of the Strategic Decision Making Process via Participant Recall: A Free Simulation Examination. Journal of Management, 13(1): 123134. 